\title{
The Effects of Different Nitrogen and Phosphorus Rates on Some Quality Traits of Potato
}

\author{
Erdoğan Öztürk • Zühal Kavurmacı • \\ Kemalettin Kara • Tașkın Polat
}

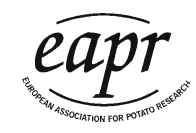

Received: 11 August 2010/Accepted: 30 October 2010/

Published online: 19 November 2010

(C) The Author(s) 2010. This article is published with open access at Springerlink.com

\begin{abstract}
This study was conducted to determine the effects of nitrogen (0, 120, and $\left.240 \mathrm{~kg} \mathrm{~N} \mathrm{ha}^{-1}\right)$ and phosphorus $\left(0,90\right.$, and $\left.180 \mathrm{~kg} \mathrm{P}_{2} \mathrm{O}_{5} \mathrm{ha}^{-1}\right)$ doses on some tuber quality traits of the potato cultivar Agria under the ecological conditions of Erzurum in the years 2005 and 2006. The effects of $\mathrm{N}$ levels were significant only on the protein content of tubers while the $\mathrm{P}$ levels only significantly affected the oil content of the crisps. No significant $\mathrm{N} \times \mathrm{P}$ interaction effects were found on any of the traits evaluated. Based on these results, it could be concluded that the potato crop should be fertilized with $120 \mathrm{kgha}^{-1} \mathrm{~N}$ and that phosphorus fertilizers should be added when soils are $\mathrm{P}$ deficient in the Erzurum region.
\end{abstract}

Keywords Crisp quality $\cdot$ Fertilization $\cdot$ Potato $\cdot$ Protein content $\cdot$ Tuber quality

\section{Introduction}

Potato is an important nutrient source in human nutrition. Increasing potato yield is required to meet the needs of an increasing human population. The yield and quality of potato are affected by variety, environmental conditions, and cultural practices. Fertilizer application has important effects on the quality and yield of potato (Westermann 2005). Potato can absorb large quantities of plant nutrients, especially nitrogen $(\mathrm{N})$, phosphorus $(\mathrm{P})$, and potassium $(\mathrm{K})$, from the soil during the growing period (White et al. 2007). An optimum dose of fertilization should be applied in order to obtain an economically optimal yield of potato. Inadequate or excess usage of fertilizers reduces tuber yield and quality.

E. Öztürk $(\triangle) \cdot K$. Kara $\cdot$ T. Polat

Faculty of Agriculture, Department of Field Crops, Ataturk University, Erzurum 25240, Turkey e-mail: erozturk@atauni.edu.tr 
Although Erzurum is an important place with respect to potato production in Turkey, its yield per unit area is quite low. One of the reasons for low yields is low fertilization. Therefore, studies on nutrient management of potato crop will be very helpful to improve both yield and quality of potatoes in the region. In a preliminary study, Kara (2002) reported the positive effects of nitrogen fertilization on specific gravity, dry matter content, crisps yield, and protein content of potato tubers while phosphorus doses were not affecting these parameters. The current study aimed to determine the effects of different nitrogen and phosphorus rates on some quality traits of potato under Erzurum conditions.

\section{Material and Methods}

The experiments were conducted at the Agricultural Research and Extension Center of the Agricultural Faculty of Ataturk University in Erzurum, Turkey, in 2005 and 2006. Erzurum city has a terrestrial climate and is located in Eastern Anatolia $\left(39^{\circ} 55^{\prime} \mathrm{N}, 41^{\circ} 61^{\prime} \mathrm{E}, 1853 \mathrm{~m}\right.$ asl). In 2005, the maximum amount of rainfall was recorded in May $(92.1 \mathrm{~mm})$ and the minimum amount was recorded in September $(15.4 \mathrm{~mm})$. In 2006, the maximum amount of rainfall was recorded in October $(90.1 \mathrm{~mm})$ and the minimum amount was observed in August $(3.5 \mathrm{~mm})$. Highest temperatures occurred in July-August and lowest temperatures in October. Mean temperatures were 12.8 and $14.1^{\circ} \mathrm{C}$ between May and October in 2005 and 2006 , respectively. Maximum and minimum relative humidities were $70.2 \%$ and $76.0 \%$ in September, and were 54.8\% and 50.9\% in August, in 2005 and 2006, respectively.

The soils at the research sites were clay-loamy-textured in 2005 and loamy in 2006 , but were poor in organic matter in both years. The soils had a slightly alkaline character ( $\mathrm{pH}$ ranged between 7.21 and 7.25) with a rather low lime content, had moderate levels of available phosphorus and high available potassium (Sezen 1991). The soil of the research area had higher lime, organic matter, phosphorus, and potassium content in the first year than in the second year.

The field experiments were laid out in a split-plot design with three replications in both years. Three nitrogen doses $(0,120$, and $240 \mathrm{~kg} / \mathrm{ha})$ were allocated to the main plots and three phosphorus doses $(0,90$, and $180 \mathrm{~kg} / \mathrm{ha})$ were allocated to the subplots. As fertilizers, triple super phosphate (45\%), potassium sulfate $(50 \%)$, and ammonium sulfate $(21 \%)$ were used in the experiments. The medium late potato cultivar Agria was used in both years due to good adaptation to the region and suitability for processing.

At planting, hills were created with a between-row distance of $70 \mathrm{~cm}$ and a within-row plant distance of $35 \mathrm{~cm}$. Each subplot had four rows with 12 hills per row. Therefore, each subplot had an area of $2.8 \mathrm{~m} \times 4.2 \mathrm{~m}=11.76 \mathrm{~m}^{2}$ and the total area per experiment was $317.52 \mathrm{~m}^{2}$. Potato tubers were planted on May 9 in 2005 and May 12 in 2006.

During crop production, cultural practices including hoeing, hilling, and irrigation were carried out uniformly on all plots. When the plants had matured, one hill from the beginning of each row to one row at each side of each subplot were discarded and then harvesting was done using a shovel. The harvested area of each plot was 
therefore $1.4 \mathrm{~m} \times 3.5 \mathrm{~m}=4.9 \mathrm{~m}^{2}$. Tubers were harvested on October 1 in 2005 and on October 4 in 2006.

After harvesting, dry matter, starch, and raw protein of tubers, and relative crisps yield and oil content of crisps were assessed. The dry matter content of tubers was determined gravimetrically by drying sliced tuber samples $(100 \mathrm{~g})$ in a forced air oven at $105{ }^{\circ} \mathrm{C}$ to a constant weight for at least $24 \mathrm{~h}$. The starch content of samples were determined by the Ewers' method. Dried tuber samples were ground and then the protein content was determined by the Kjeldahl method. For relative crisps yield, peeled tubers were sliced (1.0-1.5-mm thickness) and $100 \mathrm{~g}$ of sliced samples were fried at $190{ }^{\circ} \mathrm{C}$ for $2 \mathrm{~min}$. After the weighing of fried crisps, relative crisps yield data were calculated as percentage of fresh weight. Then, the oil content of the fried samples was determined for each treatment.

Data were subjected to analysis of variance, followed by the Duncan multiple comparison test for the means using the SPSS computer program.

\section{Results and Discussion}

The mean values for the effects of different $\mathrm{N}$ and $\mathrm{P}$ levels on evaluated quality traits of potato tubers are presented in Table 1. The effects of $\mathrm{N}$ levels were only significant for the protein content of tubers while the $\mathrm{P}$ levels only significantly affected the oil content of the crisps. No significant $\mathrm{N} \times \mathrm{P}$ interaction effects were found on any of the evaluated traits.

Table 1 Effects of different $\mathrm{N}$ and $\mathrm{P}$ rates on some quality traits of potato tubers

\begin{tabular}{llllll}
\hline Treatment & $\begin{array}{l}\text { Dry matter } \\
\text { content }(\%)\end{array}$ & $\begin{array}{l}\text { Starch } \\
\text { content }(\%)\end{array}$ & $\begin{array}{l}\text { Protein content } \\
(\% \mathrm{dwt})\end{array}$ & $\begin{array}{l}\text { Relative crisps } \\
\text { yield }(\%)\end{array}$ & $\begin{array}{l}\text { Crisps oil } \\
\text { content }(\%)\end{array}$ \\
\hline $\mathrm{N}$ rate $\left(\mathrm{kg} \mathrm{ha}^{-1}\right)$ & & & & \\
0 & 20.6 & 15.4 & $9.7 \mathrm{~b}$ & 32.8 & 35.4 \\
120 & 20.2 & 15.1 & $10.1 \mathrm{~b}$ & 33.2 & 35.0 \\
240 & 20.0 & 15.0 & $10.9 \mathrm{a}$ & 32.4 & 35.5 \\
$\mathrm{P}$ rate $\left(\mathrm{kg} \mathrm{ha}^{-1}\right)$ & & & & $36.4 \mathrm{a}$ \\
0 & 20.5 & 15.4 & 10.2 & 32.8 & $35.3 \mathrm{ab}$ \\
90 & 20.2 & 15.1 & 10.2 & 33.3 & $34.3 \mathrm{~b}$ \\
180 & 20.1 & 15.0 & 10.2 & 32.2 & 35.3 \\
Mean & 20.3 & 15.2 & 10.2 & 32.8 & $\mathrm{NS}$ \\
rate $(\mathrm{N})$ & $\mathrm{NS}$ & $\mathrm{NS}$ & $* *$ & $\mathrm{NS}$ & $*$ \\
rate $(\mathrm{P})$ & $\mathrm{NS}$ & $\mathrm{NS}$ & $\mathrm{NS}$ & $\mathrm{NS}$ & $\mathrm{NS}$ \\
$\mathrm{N} \times \mathrm{P}$ & $\mathrm{NS}$ & $\mathrm{NS}$ & $\mathrm{NS}$ & $\mathrm{NS}$ & \\
\hline
\end{tabular}

Means followed by different letters in the same column differ significantly according to the Duncan test at $P<0.05$

$N S$ not significant

*F test significant at $P<0.05$

**F test significant at $P<0.01$ 
The effects of $\mathrm{N}$ and $\mathrm{P}$ levels were similar on both dry matter and starch contents of the tubers (Table 1). Although the effects were not statistically significant, both dry matter and starch contents slightly decreased with increased $\mathrm{N}$ and $\mathrm{P}$ levels. Recently, Zelalem et al. (2009) also reported similar effects of $\mathrm{N}$ and $\mathrm{P}$ doses on dry matter content and specific gravity of potato in Ethiopia. After a long series of field experiments in the United States of America, Kunkel and Holstad (1972) also concluded that specific gravity of potato often decreased with increasing levels of $\mathrm{N}$, $\mathrm{P}$, and $\mathrm{K}$.

The protein contents of tubers significantly increased with increasing nitrogen dose (Table 1). Protein contents of dry tubers were 9.7\%, 10.6\%, and $10.9 \%$ after applying 0, 120, and $240 \mathrm{~kg} \mathrm{~N}^{-1}$, respectively. Similarly, Rexen (1976) and Leszczyński and Lisińska (1988) reported positive effects of nitrogen fertilization on the protein content of tubers. No significant effects of the $\mathrm{P}$ fertilization on the protein content of tubers were found in the experiment.

Relative yields of crisps is a function of tuber dry matter content and oil absorption rate of crisps, and no significant effect of either $\mathrm{N}$ or $\mathrm{P}$ fertilization on relative crisps yield were found in the study (Table 1); however, the oil content of crisps was significantly $(P<0.01)$ affected by the phosphorus level, and it decreased with increasing phosphorus level (Table 1). Slight increases in dry matter content of tubers with $\mathrm{P}$ fertilization probably resulted in such a decrease in crisp oil absorption.

As a result of this 2-year study, it was concluded that nitrogen doses affected the protein content, whereas phosphorus doses affected the relative oil absorption rate of crisps; however, further studies with different cultivars containing also growth and yield parameters should be conducted to develop reliable fertilization recommendations for the region.

Open Access This article is distributed under the terms of the Creative Commons Attribution Noncommercial License which permits any noncommercial use, distribution, and reproduction in any medium, provided the original author(s) and source are credited.

\section{References}

Kara K (2002) The effects of nitrogen and phosphorus applications in various planting time and at different doses on quality. 3th National Potato Congress, 23-27 September 2002, İzmir, Turkey, pp 347-363

Kunkel R, Holstad N (1972) Potato chip color, specific gravity and fertilization of potatoes with N-P-K. Am J Potato Res 49:43-62

Leszczyński W, Lisińska G (1988) Influence of nitrogen fertilization on chemical composition of potato tubers. Food Chem 28:45-52

Rexen B (1976) Studies of protein of potatoes. Potato Res 13:189-202

Sezen Y (1991) Fertilizers and fertilization. Ataturk University Faculty of Agriculture, Publication no. 679, pp 39-96

Westermann DT (2005) Nutritional requirements of potatoes. Am J Potato Res 82:301-307

White PJ, Wheatley RE, Hammond JP, Zhang K (2007) Minerals, soils and roots. In: Vreugdenhil D (ed) Potato biology and biotechnology, advances and perspectives. Elsevier, Amsterdam, pp 739-752

Zelalem A, Tekalign T, Nigussie D (2009) Response of potato (Solanum tuberosum L.) to different rates of nitrogen and phosphorus fertilization on vertisols at Debre Berhan, in the central highlands of Ethiopia. Afr J Plant Sci 3:16-24 